\title{
THE MEDIATING EFFECT OF EMOTION ON ENTREPRENEURSHIP EDUCATION AND BUSINESS OPPORTUNITY RECOGNITION
}

\author{
Nor Hafiza Othman* \\ Universiti Kebangsaan Malaysia \\ Universiti Malaysia Kelantan \\ Norasmah Othman \\ Universiti Kebangsaan Malaysia \\ Noor Hasni Juhdi \\ Universiti Kebangsaan Malaysia
}

\begin{abstract}
The purpose of this study is to determine the effect of entrepreneurial emotion on relationship between entrepreneurship education and business opportunity recognition. Entrepreneurship process begins when an entrepreneur recognizes a business opportunity that involves various emotions throughout the process. Although various activities and entrepreneurship programs are carried out in universities, the involvements of students and graduates in business start-ups are still small. The main factor is the failure to leverage potential business opportunities, which in turn, leads to the stability of emotion's reliance. A total of 152 of final year students participated in this study. The data were collected from questionnaires, and the hypotheses were tested using Partial Least Square - Structural Equation Modeling (PLS-SEM). The findings indicated that entrepreneurship education, emotion and opportunity recognition were significantly related. It was also found that entrepreneurial emotion partially mediated the relationship between entrepreneurship education and opportunity recognition. The findings have confirmed that although entrepreneurship education helps improve students' capabilities to adapt to new environments, and recognizes the potential of business opportunities, a stable emotion is crucial throughout the entire entrepreneurship process.
\end{abstract}

Keywords: Entrepreneurship Education; Emotion; Opportunity Recognition; Mediator

Received: 31 January 2019

Accepted: 16 October 2020

\section{INTRODUCTION}

The importance of entrepreneurship education (EE) in developing a country's economy is undisputed. The EE in Higher Learning Institutions (HLI's) became increasingly popular after the University of Southern California offered it in 1971, and today, the number of colleges and universities offering the course has exceeded three thousand worldwide (Kuratko \& Morris, 2017).

\footnotetext{
- Corresponding author: Faculty of Entrepreneurship and Business, Universiti Malaysia Kelantan, 16100 Pengkalan Chepa, Kelantan, Malaysia. E-mail: hafiza.o@umk.edu.my
} 
This is in line with some studies showing the capability of entrepreneurship education in increasing the tendency of students to engage in entrepreneurial activity (Jiang \& Wang, 2014; Linan, Nabi \& Krueger, 2013; Sanchez \& Sahuquillo, 2018), developing entrepreneurial attitudes like being innovative, creative, proactive and competitive (Dumitrache \& Raileanu, 2014) and subsequently starting a venture (Lackeus, 2015). So, EE is a process that can increase the number of entrepreneurs and help develop students' competencies in terms of knowledge, skills and entrepreneurial attitudes.

The Ministry of Higher Education Malaysia has taken the initiative to ensure entrepreneurship courses to be compulsory for all students in public universities beginning in 2013. At the same time, students are encouraged to participate in various entrepreneurship activities at their universities such as entrepreneurship trainings, seminars and exhibitions. This is in line with the Entrepreneurship Development Policy of HLI's which implements the three key components of entrepreneurial values and skills among university students namely (i) awareness; (ii) cultures; and (iii) consolidation (EPU, 2010). After the five years period of the implementation of HEIs on Entrepreneurship Development Policy and various initiatives under the Entrepreneurship Strategic Plan 2013-2015, the sensitivity and acceptance of local HEIs on the interests and agenda of entrepreneurship education have been successfully enhanced. This is evidenced by the increase of the level of involvement and participation of students in entrepreneurship programs and activities, which show a significant climb from less than $20 \%$ in 2011 to more than $50 \%$ by 2015 (Ministry of Higher Education, 2016).

Besides that, entrepreneurial activities involve various emotions that play important roles in implementing entrepreneurship process. Some researchers have proven that emotions affect individuals in making judgments and decisions in business (Welpe, Sporrle, Grichnik, Michl, \& Audretsch, 2012; Zampetakis, Kafetsios, \& Moustakis, 2017). A previous research has empirically proven that business venturing, especially in a developing country like Malaysia, requires positive psychological states (Juhdi \& Juhdi, 2013) such as positive emotion (Cacciotti, Hayton, Mitchell \& Giazitzoglu, 2016; Foo, 2011). Several other studies also stated that positive emotions may boost the entrepreneurial creativity including entrepreneurial opportunity (Baron, 2008), overcoming stress (Carver \& Scheier, 2000) and also making decision (Foo, 2011). This shows that when making an action or a decision, each individual will take their feelings into account. Therefore, individual emotions affect the actions that will be taken, whether the matter is enjoyable or otherwise.

Furthermore, the study of emotion was acknowledged by previous researchers especially in psychology, but less attention was placed in entrepreneurship (Cardon, Foo, Shepherd, \& Wiklund, 2012). Whereas, entrepreneurial emotion affects entrepreneurship process (Baron, 2008; Cacciotti et al., 2016). Entrepreneurship process begins when an entrepreneur recognizes business opportunities that occur in an uncertain environment and exploits such opportunities (Bakker \& Shepherd, 2017). This means, through business opportunities sought, entrepreneurs can identify new ways of producing products and services or improve existing products. This is agreed by Kuckertz, Kollmann, Krell, and Stockmann (2017) who suggested that such ability can help an entrepreneur to take advantage of the available opportunities while possessing the characteristics of a successful entrepreneur, to create a profitable business (Ardichivili, Cardozo, \& Ray, 2003; Short, Ketchen, Shook, \& Ireland, 2010). 
Based on the Department of Statistics Malaysia (2017), the unemployment rate is rising every year, namely $3.4 \%$ in 2016 , with $0.3 \%$ increment compared to the previous year. Indirectly, opportunities for employment among graduates have also become limited. The rising unemployment rate happens due to the rapid increase of number of students, and the number of institutions in higher education today. Therefore, the difficulty of graduate students to secure employment after graduation has led the government to encourage them to opt for entrepreneurship as their primary careers (Ooi \& Nasiru, 2015; Othman \& Othman, 2017). Furthermore, entrepreneurship is a complex process, requiring complicated explanation. Some researchers stated that the factors causing graduates not to venture into entrepreneurship is because of the failure to assess the environment, the fear of failure, insufficient financial resources, and difficulties in identifying and exploiting opportunities (Cacciotti et al., 2016; Gielnik, Frese, Graf, \& Kampschulte, 2012; Schmitt, Rosing, Zhang, \& Leathherbee, 2017).

This is parallel to Ilonen, Heinonen, and Stenholm (2018), that it is still unclear on how potential students who become entrepreneurs make decisions during the process of business creation. How about the emotional effects after the exposure to entrepreneurship education and entrepreneurship process, particularly in opportunity recognition? This study adopted a mediation approach to examine the phenomenon where the direct and indirect effects of emotion on entrepreneurship education and opportunity recognition can be assessed. The researchers used segmentation approach recommended by Rungtusanatham, Miller, and Boyer (2014) to test the effect of emotion as a mediator. Moreover, emotional studies are increasingly gaining attention in entrepreneurship, but there is a lack of empirical studies on entrepreneurship education (Lackeus, 2015) and business opportunity (Kuckertz et al., 2017; Zampetakis, Lerakis, Kafetsions, \& Moustakis, 2016). Whereas, emotion plays an important role to determine a judgment or action to be taken. Therefore, there are still dimensions that allow this study to be conducted.

\section{LITERATURE REVIEW}

There are still confusions in the use of entrepreneurship education and business education terms (Buang, 2002; Lackeus, 2015). The term entrepreneurship education is often used in Canada and the United States, while the use of business education term is common in the United Kingdom (Lackeus, 2015). In addition, the term used in Finland is 'internal entrepreneurial education' and 'external entrepreneurial education', whereby internal entrepreneurial education refers to business education, while external entrepreneurial education refers to entrepreneurial education. In simpler terms, internal entrepreneurial education, refers to intrapreneurship. Therefore, entrepreneurship education is more comprehensive than business education, as it encompasses the combination of business education and entrepreneurial career orientation.

Entrepreneurship education is a process to develop student competencies such as entrepreneurial attitude, knowledge and skills (Ahmed, Chandran, \& Klobas, 2017; Ipate \& Parvu, 2014;) and to encourage them to recognize opportunity and establish a new business (Kollmann, Stockmann, \& Kensbock, 2017). With entrepreneurship education, it can help to improve individual capabilities and adapt to new environments more quickly (Echols, 2010). Some researchers state that entrepreneurial skills can be learned by exposing entrepreneurial knowledge to students (Mohd Nor, Fakhrul \& Mohamed, 2015; Othman, Othman, \& Ismail, 2012). This means, students with entrepreneurial knowledge are more likely to be in business than those who have not been exposed 
to such knowledge. Therefore, it is not surprising that entrepreneurship education has become the main focus of education ministries to students in either primary, secondary or tertiary level.

Entrepreneurship process begins when an entrepreneur recognizes opportunities that occur in an uncertain environment and exploits such opportunities (Bakker \& Shepherd, 2017). Lumpkin and Lichtenstein (2005) pointed out that opportunity is the ability of entrepreneurs to recognize potential ideas and turn them into business opportunities that bring values to customers and increase their profits. This means that through the sought business opportunities, entrepreneurs can identify new ways of producing products and services, or improve existing products. There are incentives to entrepreneurship lecturers to increase student perceptions or emotions towards entrepreneurship through more effective teaching and learning environment (Zampetakis et al., 2016).

The human capital theory will underline this study, which explains that individuals of high quality will achieve better performance in carrying out a task (Werner \& DeSimone, 2011). This theory is one of the most widely used theories, relating to the willingness and ability to recognize business opportunities (Unger, Rauch, Frese, \& Rosenbusch, 2011). Several studies showed the effectiveness of entrepreneurship education in developing students' entrepreneurial skills and knowledge through business plans, marketing, financial, networking, business ideas, controlling risks and uncertainties (Bagheri \& Pihie, 2013; Lackeus, 2015; Othman \& Othman, 2017; Rusok, Kumar, \& Ahmed, 2017). Indirectly, the exposure of entrepreneurship education to students can increase their abilities to recognize opportunities. They will become quicker and efficient on any market condition, and this can reduce the probability to go out of business. Therefore, understanding the emotions of students to start a business is a way to predict their goals and actions (Miceli \& Castelfranchi, 2014).

Besides that, due to the uncertain economic conditions and a limited supply of labour, students who have positive emotions towards entrepreneurship will be able to control the situation and seek business opportunities and become job creators. This is supported by Baron (2008), who stated that emotions are expected to have greater cognitive influence in assessing unpredictable and expected situation. It means emotions will change the focus or attention of students, and it affects their performance. Thus, entrepreneurial emotion is very relevant in the context of entrepreneurship education in preparing university students to choose entrepreneur as a career. Furthermore, the government also stressed that the formation of a holistic and integrated curriculum (Ministry of Higher Education, 2016) is in line with the National Education Philosophy to produce individuals who are intellectually, spiritually, emotionally and physically balanced and harmonic. This shows that entrepreneurship education curriculum plays an important role for the students and potential entrepreneurs to be holistic, resilient and able to compete in global markets. Therefore, the hypothesis is as follows:

\section{$H_{1}$ : Entrepreneurship education has a positive effect on entrepreneurial emotion}

Nowadays, emotional studies are increasingly gaining attention in entrepreneurship, but there is a lack of empirical studies on entrepreneurial education in influencing student emotions in entrepreneurial activity (Lackeus, 2015; Othman, Othman, \& Juhdi, 2019). Entrepreneurial emotions refers to affects, emotions, feelings or moods (Cardon et al., 2012). They added that entrepreneurship creates a great emotion in terms of time strain, ambiguity and personal feeling. 
According to Foo (2011), emotions can affect the assessment of an opportunity, but the influence of emotions in entrepreneurship research has been neglected. Emotions arise from an individual's interpretation and explanation for a given situation (Imada \& Ellsworth, 2011). It means the judgment (or appraisal) of a situation, event or object can determine or contribute to the emotional response. When individuals have positive emotions, they will think more flexibly, creatively, with a bigger picture of what to do. Positive emotions include pleasurable responses to actions such as joy, satisfaction, excitement, happiness and hope (Cacciotti et al., 2016; Foo, 2011; Zampetakis et al., 2016). Indirectly, these emotions will affect the way they recognize entrepreneurial opportunities. The following hypothesis is proposed:

\section{$\mathrm{H}_{2}$ : Entrepreneurial emotion has a positive effect on business opportunity recognition.}

Besides that, entrepreneurship education should emphasize on opportunities, as it is the core of entrepreneurship (Kuratko \& Morris, 2017; Schmitt et al., 2017). This is supported by Short et al., (2010) emphasizing that the focus of entrepreneurship should be to entrepreneurial opportunity because without opportunities, entrepreneurship will not exist. In addition, various emotions are expected to be the determinant of a behaviour or an action in entrepreneurship (Welpe et al., 2012; Zampetakis et al., 2016). Some studies encourage the students to engage in entrepreneurial lifeworld which emphasized the feelings of students over what they would like to be as entrepreneurs (Pless, Maak, \& Stahl, 2011). Therefore, experiential learning is an effective way to influence students to become job creators, and indirectly, they will also be exposed to entrepreneurial process and behaviours.

This is agreed by Foo (2011), who said that emotion is a critical factor in entrepreneurial process and it has a strong influence in starting a business (Baron, 2008). When any individuals feel comfortable or happy, they investigate their situations as their own. Interestingly, people feel angry or scared considering their situation is no longer under their control (Lerner \& Keltner, 2001). It is important to discover the feelings of the students, whether they are inspired or obstructed when they want to start a business, following that many entrepreneurial activities are undertaken by universities and the government to inculcate entrepreneurship. Therefore, anticipated emotions that have advantages in influencing any actions and exposures to entrepreneurship education is important, since they affect emotions toward entrepreneurship. In this manner, it is hypothesised that:

\section{$H_{3}$ : Entrepreneurial emotion mediates the relationship between entrepreneurship education and business opportunity recognition.}

Based on the literature reviews, Figure 1 shows the research model that has been developed. In this study, the researchers did not follow the Baron and Kenny's method that it is a must to test direct relationship between $\mathrm{X}$ (entrepreneurship education) and Y (opportunity recognition). Furthermore, this study aims to test the effect of emotion as mediator on the relationship between entrepreneurship education and business opportunity recognition. According to Ramayah, Cheah, Chuah, Ting and Memon (2018), if a researcher claims that X affects $\mathrm{Y}$ because of M, then testing direct relationship is of less importance. This is similar with Hair, Ringle and Sarstedt (2013) that when testing mediating effects, the researchers should rather follow Preacher and Hayes method (indirect effect-bootstrapping). Therefore, to test the mediation effect, the researchers used segmentation approach recommended by Rungtusanatham et al., (2014). It considers that at least 
three hypotheses need to test direct and indirect effects; $\left(\mathrm{H}_{1}\right)$ entrepreneurship education on entrepreneurial emotion, $\left(\mathrm{H}_{2}\right)$ entrepreneurial emotion on business opportunity recognition, and $\left(\mathrm{H}_{3}\right)$ entrepreneurial emotion mediates the effect of entrepreneurship education and business opportunity recognition.

Figure 1: Research Model

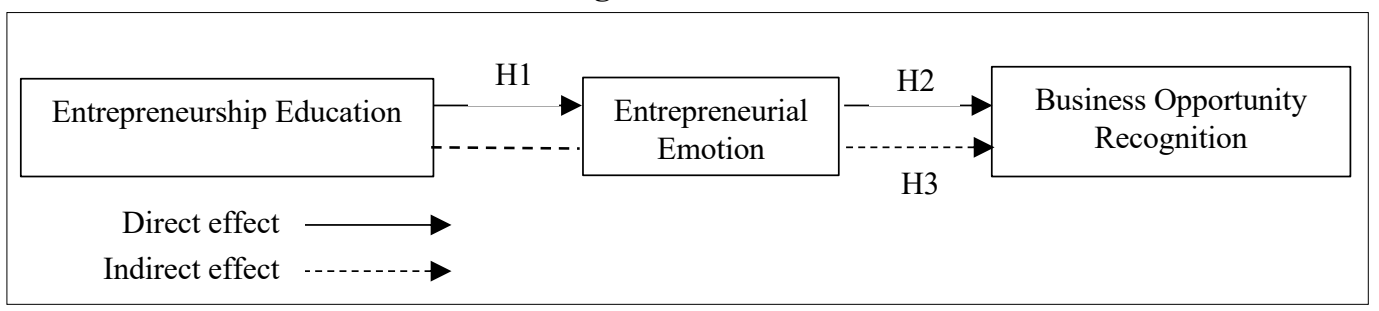

\section{METHODOLOGY}

\subsection{Samples}

A quantitative survey was conducted on the 152 final year students pursuing first degree studies from a public university. This study uses purposive sampling technique that focuses on final year students. Final year students were chosen for this study due to the future plans and careers that they have upon graduation. In fact, they have also undertaken entrepreneurship courses during their first year of study at the university. In this study, the researchers used the Gpower software to calculate the minimum sample size required. Since the research model has only one predictor, we set the effect size as 0.15 and the power needed as 0.95 . The sample size required was 89 . A total of 160 questionnaires were distributed and 152 were returned, yielding a response rate of 95.00 percent

\subsection{Instrument}

In this study, questionnaire is the main instrument. The distributed questionnaire consisted of four sections. The first part was the respondents' profiles covering gender, ethnicity, study courses, and entrepreneurial experience. The second part queried entrepreneurship education, followed by opportunity recognition and entrepreneurial emotion. Entrepreneurship education is referred to a process in developing entrepreneurial skills and knowledge among students. It was measured using 12 items based on ten-point Likert scale anchored from not at all (1) to a very high (10) and the items have been adapted (Lackeus, 2015; Othman \& Othman 2017). On the other hand, seven measurement items for business opportunity recognition was adapted from Kuckertz et al., (2017) and Reynolds (2016). Business opportunity recognition is referred to the students' action for searching information and becoming alert to potential opportunities to be exploited. For items of business opportunity recognition and entrepreneurial emotion, respondents were answered on a seven-point Likert scale, whereby $1=$ strongly disagree and $7=$ strongly agree. While, in this context, entrepreneurial emotion is an anticipation of positive emotions among students to start a business. It was measured by five items and adapted from Foo (2011) and Zampetakis et al., (2016). 
Respondents were asked about the anticipation of happiness, pleasure, excitement, pride and hope of doing business.

\subsection{Validity and Reliability}

Eight experts were involved to get their consents for each concept and items used in this survey, to measure the content validity. Based on the content validity index for each item (I-CVI), the value of entrepreneurship education (0.92), entrepreneurial emotion (0.93) and opportunity recognition (0.94). The results showed that the contents of the questionnaire had a good validity since its value exceeded 0.90 (Stewart \& Haswell, 2013). For face validity, the draft questionnaire was checked by all experts and 20 students before the pilot study was run. Then, to measure reliability, the value of Cronbach's Alpha was used and the value for entrepreneurship education is 0.89 , entrepreneurial emotion (0.91) and business opportunity recognition (0.92). The results show that all variables have exceeded the required value of 0.6 (Sekaran \& Bougie, 2016). Therefore, this instrument can be used for the actual study.

\subsection{Common Method Bias}

According to Podsakoff, MacKenzie, Lee, \& Podsakoff (2003), it is important to check common method variance when the data were collected from a single source. Harman's single factor test was conducted and the results indicated that the first factors explained $38.30 \%$ of the variance, which was $<50 \%$ as recommended by Podsakoff et al., (2003). Additionally, the cumulative variance $(65.01 \%)$ was explained by three factors and the value was higher than the suggested value of $50 \%$. Therefore, in this study, the common method bias carries no issue.

Table 1: Profile of Respondents

\begin{tabular}{lcc}
\hline \hline & Frequency & Percentage (\%) \\
\hline Gender & 37 & 24.3 \\
Male & 115 & 75.7 \\
Female & & \\
& & \\
Ethnicity & 132 & 86.8 \\
Malay & 11 & 7.2 \\
Chinese & 9 & 6.0 \\
Indian & & \\
& & \\
Courses & 43 & 28.3 \\
Science & 75 & 49.3 \\
Social Science & 34 & 22.4 \\
Technical & & \\
Experience & 119 & 78.3 \\
Yes & 33 & 21.7 \\
No & & \\
\hline \hline
\end{tabular}

Table 1 indicates the respondents' demographics, in which $24.3 \%$ of the students were males and $75.7 \%$ of them were females. Most of the students belonged to Social Science (49.3\%), Science 
(28.3\%) and Technical (22.4\%). The majority of the students were Malay (86.8\%), followed by Chinese $(7.2 \%)$ and Indian $(6.0 \%)$. All of the students had taken entrepreneurship course in their first year of study, and most of them (78.3\%) had experience in business.

\section{RESULTS AND DISCUSSION}

This study predicts the relationship between the variables in the research model. So, the researchers used the Smart PLS version 3.0, which is a variance-based structural equation modeling (SEM) to test the hypothesis. There are two steps of analytical procedures to evaluate the measurement and structural models. The bootstrapping method (5000 resamples) was utilized to determine the loading and path coefficients (Hair, Hult, Ringle, \& Sarstedt, 2014).

\subsection{Measurement Model}

In this study, the researchers assessed convergent validity according to the suggestion by Hair et al., (2014). They suggested that the loading should be $>0.70, \mathrm{CR}>0.7$ and AVE $>0.5$. As shown in Table 2, the AVE was greater than 0.5 and the CR was greater than 0.7 . All the loading values were above the cut-off, 0.70 except item A7 (0.672). However, the researchers did not delete the item because the AVE result achieved 0.5, as recommended by Ramayah et al., (2018), whereby a loading lower than 0.7 can be kept if AVE result is greater than 0.5. Thus, all constructs have sufficient internal consistency reliability.

Table 2: Measurement Model

\begin{tabular}{|c|c|c|c|c|}
\hline Construct & Item & Loadings & AVE & CR \\
\hline \multirow[t]{12}{*}{ Entrepreneurship Education } & A1 & 0.737 & 0.564 & 0.939 \\
\hline & A2 & 0.701 & & \\
\hline & A3 & 0.803 & & \\
\hline & A4 & 0.804 & & \\
\hline & A5 & 0.812 & & \\
\hline & A6 & 0.772 & & \\
\hline & A7 & 0.672 & & \\
\hline & A 8 & 0.753 & & \\
\hline & A9 & 0.745 & & \\
\hline & A10 & 0.782 & & \\
\hline & A11 & 0.707 & & \\
\hline & A12 & 0.745 & & \\
\hline Opportunity & B1 & 0.750 & 0.653 & 0.929 \\
\hline \multirow[t]{6}{*}{ Recognition } & B2 & 0.829 & & \\
\hline & B3 & 0.867 & & \\
\hline & B4 & 0.812 & & \\
\hline & B5 & 0.821 & & \\
\hline & B6 & 0.834 & & \\
\hline & B7 & 0.737 & & \\
\hline \multirow[t]{5}{*}{ Emotion } & $\mathrm{C} 1$ & 0.870 & 0.814 & 0.956 \\
\hline & $\mathrm{C} 2$ & 0.925 & & \\
\hline & $\mathrm{C} 3$ & 0.922 & & \\
\hline & $\mathrm{C} 4$ & 0.913 & & \\
\hline & $\mathrm{C} 5$ & 0.879 & & \\
\hline
\end{tabular}


Then, the researchers assessed discriminant validity following Fornell and Larcker (1981) in Ramayah et al., (2018) which compared the square roots of the AVE with the correlations as presented in Table 3. The square correlations for each construct are lower than the AVE by the indicators measuring constructs, indicating adequate discriminant validity. Overall, the measurement model showed adequate convergent validity and discriminant validity.

Table 3: Discriminant Validity

\begin{tabular}{lccc}
\hline \hline & $\begin{array}{c}\text { Entrepreneurial } \\
\text { Emotion }\end{array}$ & $\begin{array}{c}\text { Entrepreneurship } \\
\text { Education }\end{array}$ & $\begin{array}{c}\text { Business } \\
\text { Opportunity } \\
\text { Recognition }\end{array}$ \\
\hline Entrepreneurial Emotion & $\mathbf{0 . 9 0 2}$ & $\mathbf{0 . 7 5 1}$ & \\
Entrepreneurship Education & 0.451 & 0.576 & $\mathbf{0 . 8 0 8}$ \\
Business Opportunity & 0.485 & & \\
Recognition & & &
\end{tabular}

\subsection{Structural Model}

To evaluate the structural model, it can be assessed through the explanatory power of the model (R2), effect size (f2) and path coefficient (Hair et al., 2014). Then, bootstrapping procedure with 5000 subsamples was calculated for the hypothesis relationship.

Table 4: Hypothesis Testing on Direct Effect

\begin{tabular}{|c|c|c|c|c|c|c|c|}
\hline No & Relationship & $\begin{array}{l}\text { Std. } \\
\text { Beta }\end{array}$ & $\begin{array}{l}\text { Std. } \\
\text { Error }\end{array}$ & $\begin{array}{c}\text { t- } \\
\text { value }\end{array}$ & Decision & $\overline{\mathbf{R}^{2}}$ & $\overline{f^{2}}$ \\
\hline $\mathrm{H}_{1}$ & $\begin{array}{l}\text { Entrepreneurship Education } \rightarrow \\
\text { Emotion }\end{array}$ & 0.451 & 0.057 & 7.970 & Supported & 0.203 & 0.255 \\
\hline $\mathrm{H}_{2}$ & $\begin{array}{l}\text { Emotion } \rightarrow \\
\text { Recognition }\end{array}$ & 0.485 & 0.053 & 9.099 & Supported & 0.236 & 0.308 \\
\hline
\end{tabular}

From the analysis (Table 4), it was found that entrepreneurship education ( $\beta=0.451, t=7.970$, $\mathrm{p}<0.05$ ) had a positive effect on entrepreneurial emotion with an explained variance of $20.3 \%$. While the effect size showed that entrepreneurship education $\left(\mathrm{f}^{2}=0.255\right)$ had a moderate effect on entrepreneurial emotion. The findings showed that entrepreneurship education that had been exposed to students had a positive effect on their emotions in starting a business. They became more excited and pleased to carry out entrepreneurship activity. This is in line with Kollmann et al., (2017) and Lackeus (2014) who showed that the students' emotions can determine whether a vulnerable student with entrepreneurship education will create a business or not. In the context of this study, all of the students were exposed to entrepreneurial courses when they were in their first year of study. Caccioti et al., (2016) added that individuals who cannot control their emotions will use that factor as an obstacle to start a business. Thus, the exposure of entrepreneurship education to students is essential in enhancing entrepreneurial competencies, whereby they will be more prepared with any possibility and their emotions will be more stable.

In addition, entrepreneurial emotion was found to have a positive effect on opportunity recognition ( $\beta=0.485, \mathrm{t}=9.099, \mathrm{p}<0.05$ ), accounting for as much as $23.6 \%$ of the variance and had a moderate effect on opportunity recognition $\left(\mathrm{f}^{2}=0.308\right)$. In this study, the positive emotion affects the 
capabilities of students to recognize the opportunity. Emotion is a critical factor in the entrepreneurial process (Schmitt et al., 2017) and various emotions are expected to be the assessment of opportunity (Foo, 2011) and determinant of action (Othman et al., 2019; Zampetakis et al., 2016). This result is also parallel to Cacciotti et al., (2016) which show that the effect of emotions on entrepreneurship process by which entrepreneurs experience anxiety at various points throughout the process. The findings indicate that when an entrepreneur has a disturbed emotion, it will influence the action to be taken and affect the performance of a task. Thereby, emotion is very important to ensure exploration and recognition of entrepreneurial opportunities for the survival of businesses. Thus, the result provides sufficient evidence to support $\mathrm{H} 1$ and $\mathrm{H} 2$.

Besides that, the indirect effect was significant $(\beta=0.451, t=7.228 ; \mathrm{p}<0.05)$, indicating that there was a mediation (Table 5).Variance Accounted For (VAF) was used to determine the size of the indirect effect in relation to the total effect as suggested by Hair et al., (2014). The result indicated that VAF for this study is $49.97 \%$ which was classified as partial mediation. So, the relationship between entrepreneurship education and opportunity recognition was mediated by entrepreneurial emotion. This hypothesis (H3) was supported. The experience gained through entrepreneurial education will provide students with skills, knowledge, and networking to cope with the challenging business environment and thus identify potential opportunities to start a business.

Table 5: Hypothesis Testing on Indirect Effect

\begin{tabular}{llcccccc}
\hline No & \multicolumn{1}{c}{ Relationship } & $\begin{array}{c}\text { Std. } \\
\text { Beta }\end{array}$ & $\begin{array}{c}\text { Std. } \\
\text { Error }\end{array}$ & $\begin{array}{c}\text { t- } \\
\text { value }\end{array}$ & \multicolumn{2}{c}{$\begin{array}{c}\text { Confidence } \\
\text { Interval (BC) } \\
\text { LL }\end{array}$} & UL \\
\hline $\mathrm{H}_{3}$ & $\begin{array}{l}\text { Entrepreneurship Education } \rightarrow \\
\text { Emotion } \rightarrow \text { Business Opportunity } \\
\text { Recognition }\end{array}$ & 0.219 & 0.042 & 5.227 & 0.145 & 0.279 & Supported \\
& & & & & & \\
\hline \hline
\end{tabular}

This study demonstrates that emotion is a mediator between the relationship between entrepreneurship education and business opportunity recognition. This means, positive emotions include a pleasant response to an action and increase capabilities. This is in line with some researchers who claimed that individuals who have positive emotions will perform a particular task easier (Wah, Zawawi, Yusof \& Sambasivan, 2018; Lackeus, 2015) and engage in business (Welpe et al., 2012). So, it is not surprising that entrepreneurship lecturers undertake various initiatives in teaching to ensure learning to take place more effectively. Therefore, entrepreneurship education affects student emotions, whether it is difficult or not for them to carry out business activities and become a job creators.

\section{CONCLUSION}

The ability to capture and capitalize business opportunities are very important and fundamental in the process of entrepreneurship (Kuratko \& Morris, 2017). Without opportunity, entrepreneurship would not exist as it is the starting point of a venture. Hence, the exposure of entrepreneurship education is important to improve the quality of human capital and thus start a business. With entrepreneurship education, it can help to improve individuals' capabilities and adapt to new environments more quickly (Echols, 2010). This study shows that entrepreneurship education 
affects students' emotions. This means, to improve the quality of human capital, emotional elements need to be emphasized. Parallel to this, entrepreneurship creates a great emotion in terms of time strain, ambiguity and personal feeling (Cardon et al., 2012). This is acknowledged by Hindle, Klyver, and Jennings (2009), who said that entrepreneurship-related psychosocial assets allow some individuals to behave more effectively and efficiently in the marketplace than others. This is consistent with the Philosophy of National Education to create individuals who are intellectually, spiritually, emotionally and physically balanced and harmonic. Therefore, the curriculum of entrepreneurship education plays an important role for the students and potential entrepreneurs to be holistic, resilient and able to compete in global markets

In addition, it is important to identify students' emotions, whether or not they are motivating factors to start a business, following the many entrepreneurial activities undertaken by the university to cultivate entrepreneurship to them. This is in line with Miceli and Castelfrabchi (2014), who mentioned that understanding the emotions of students is a way to predict their goals and actions to start a business. Besides that, the results of this study show that positive emotions will have a significant impact on recognizing entrepreneurial opportunities. Indirectly, it will exhibit a sense of joy and fun for the actions to be undertaken. This shows that entrepreneurship learning at the university is not only important to increase the competency of students to become entrepreneurs, but also emotionally. When they feel happy about something, they will be more positive and tend to do it. Otherwise, if they feel uncomfortable, doing it is unlikely to happen. Hence, understanding the students' emotions is very important to prepare them to become job creators. Thus, the teaching approaches used by entrepreneurship lecturers are important to raise the students' awareness and competencies on entrepreneurship and also attract them to venture into entrepreneurship.

Lecturers should incorporate practical experiences and theoretical teachings to make learning processes become more effective. Among the techniques that can be used are simulations. With such techniques, classroom learning will be more interactive and entertaining. It is acknowledged by Sarfraz, Badar, Khattak, and Imtiaz (2018), that high intellectual stimulation allows lecturers to deliver entrepreneurship education with innovative and challenging methods such as experiential learning and problem solving. This will increase the students' interests in learning entrepreneurship (Othman et al., 2012) and subsequently encourage them to engage in business activities (Welpe et al., 2012).

In addition, new mediation relationships have been hypothesized, emotionally as a mediator of the relationship between entrepreneurship education and entrepreneurship opportunities. The findings have confirmed that emotion is important throughout entrepreneurial process. Therefore, the results of this study contribute to the involvement of lecturers, universities or policymakers to plan a more comprehensive curriculum and teaching techniques that will be used to ensure learning to become more effective. Indirectly, the objectives of entrepreneurship education in universities will be reached, and the potentials of students to become job creators will increase. In this study, the researchers focused on positive emotions as a mediator, whereas future research should be done by emphasizing negative emotions to determine potential opportunities and entrepreneurial actions. This is due to the presence of negative emotions that will hamper an individual from performing a particular task. 


\section{REFERENCES}

Ahmed, T., Chandran, V. G. R., \& Klobas, J. (2017). Specialized entrepreneurship education: Does it really matter? Fresh evidence from Pakistan. International Journal of Entrepreneurial Behavior \& Research, 23(1), 4-19.

Ardichivili, A., Cardozo, R. N., \& Ray, S. (2003). A theory of entrepreneurial opportunity identification and development. Journal of Business Venturing, 18(1), 105- 123.

Bakker, R. M., \& Shepherd, D. A. (2017). Pull the plug or take the plunge: Multiple opportunities and the speed of venturing decisions in the Australian mining industry. Academy of Management Journal, 60(1), 130-155.

Bagheri, A., \& Lope Pihie, Z. A. (2013). Role of University Entrepreneurship Programs in Developing Students' Entrepreneurial Leadership Competencies: Perspectives From Malaysian Undergraduate Students. Journal of Education for Business, 88(1), 51-61.

Baron, R. A. (2008). The role of affect in the entrepreneurial process. Academy of Management Review, 33(2), 328-340.

Buang, N.A. (2002). Asas Keusahawanan. Shah Alam: Penerbit Fajar Bakti.

Cacciotti, G., Hayton, J.C., Mitchell, J.R., \& Giazitzoglu, A., (2016). A reconceptualization of fear of failure in entrepreneurship. Journal of Business Venturing, 31(3), 302-325.

Cardon, M. S., Foo, M. D., Shepherd, D., \& Wiklund, J. (2012). Exploring the heart: Entrepreneurial emotion is a hot topic. Entrepreneurship Theory and Practice, 36, 1-10.

Carver, C. S., \& Scheier, M. F. (2000). Scaling back goals and realibration of the affect system are processes in normal adaptive self-regulation: understanding "response shift" phenomena. Social Science and Medicine, 50(1), 1715-1722.

Department of Statistics Malaysia (2017). Malaysia Labour Statistics. Retrieved from https://www.dosm.gov.my/v1/index.php?r=column/pdfPrev\&id=aEdIelhlVTBtOHhjOUx qcXhyc2pCUT09

Dumitrache, V., \& Raileanu, S. M. (2014). The role of business education provided through lifelong learning in enhancing profesional competencies. Amfiteatru Economic Journal, 16(37), 874-884.

Echols, D. G. (2010). The relationship between post-secondary international business education and American expatriate managerial success. Research Report. University Of Phoenix

Economic Planning Unit (EPU) (2010). Tenth Malaysia Plan 2011-2015. Retrieved from https://www.pmo.gov.my/dokumenattached/RMK/RMK10_E.pdf

Foo, M. D. (2011). Emotions and entrepreneurial opportunity evaluation. Entrepreneurship: Theory and Practice, 35(2), 375-393.

Gielnik, M. M., Frese, M., Graf, J. M., \& Kampschulte, A. (2012). Creativity in the opportunity identification process and the moderating effect of diversity of information. Journal of Business Venturing, 27, 559-576.

Hair, J. F., Hult, G. T. M., Ringle, C. M., \& Sarstedt, M. (2014). A Primer on Partial Least Squares Structural Equation Modeling (PLS-SEM) $\left(4^{\text {th }}\right.$ Ed.). Thousand Oaks, CA: Sage.

Hair, J. F., Ringle, C.M., \& Sarstedt, M. (2013). Partial least squares structural equation modeling: Rigorous applications, better results and higher acceptance. Long Range Planning, 46(1-2), $1-12$.

Hindle, K., Klyver, K., \& Jennings, D. F. (2009). An informed intent model: Incorporating human capital, social capital and gender variables into the theoretical model of entrepreneurial intentions. In Carsrud, A. L., \& Brannback, M. (Eds), Understanding the Entrepreneurial Mind, (pp. 35-50). New York: Springer. 
Imada, T., \& Ellsworth, P.C. (2011). Pround americans and lucky Japanese: Cultural differences in appraisal and corresponding emotion. Emotion, 11(2), 329-345.

Ipate, D. M., \& Parvu, I. (2014). Entrepreneurial education as a success factor for the Romanian SMEs. Economics, Management and Financial Markets, 4(1), 247-254.

Jiang, Z., \& Wang, Z. (2014). Entrepreneurial intention and outcome expectancy: Evidence from South Korea and China. Contemporary Management Research, 10(3), 251-270.

Juhdi, N. H., \& Juhdi, N. (2013). Entrepreneurial success from positive psychology view. In 4th International Conference on Business and Economic Research (pp. 285-295). Bandung, Indonesia.

Kollmann, T., Stöckmann,C., \& Kensbock, J. M. (2017). Fear of failure as a mediator of the relationship between obstacles and nascent entrepreneurial activity-An experimental approach. Journal of Business Venturing, 1-22.

Kuckertz, A., Kollmann, T., Krell, P., \& Stockmann, C. (2017). Understanding, differentiating, and measuring opportunity recognition and opportunity exploitation. International Journal of Entrepreneurial Behavior \& Research, 23(1), 78 - 97.

Kuratko, D. F., \& Morris, M. H. (2017). Examining the Future Trajectory of Entrepreneurship. Journal of Small Business Management, 56(1), 12-19.

Lackeus, M. (2014). An emotion based approach to assessing entrepreneurial education. International Journal of Management Education, 12(3), 374-396.

Lackeus, M. (2015). Entrepreneurship in Education-What, Why, When, How. Retrieved from https://www.oecd.org/cfe/leed/BGP_Entrepreneurship-in-Education.pdf

Lerner, J. S., \& Keltner, D. (2001). Fear, anger and risk. Journal of Personality and Social Psychology, 81(1), 146-159.

Linan, F., Nabi, G., \& Krueger, N. (2013). British and Spanish entrepreneurial intentions: A comparative study. Revista de Economía Mundial, 33, 73-103.

Lumpkin, G. T., \& Lichtenstein, B. B. (2005). The role of organizational learning in the opportunity recognition process. Entrepreneurship Theory and Practice, 29(4), 451-472.

Miceli, M., \& Castelfranchi, C. (2014). Expectancy and Emotions. Oxford: Oxford University Press.

Ministry of Higher Education. (2016). Entrepreneurship Action Plan of Higher Learning Institutions 2016-2020. Putrajaya: Malaysia.

Mohd Nor Hakimin, Fakhrul Anwar \& Mohamed Dahlan. (2015). Entrepreneurship education in Malaysia's public institutions of higher learning-A review of the current practices. International Education Studies, 8(1), 17-28.

Ooi, Y. K., \& Nasiru, A. (2015). Entrepreneurship education as a catalyst for business start-ups: A study on Malaysian community college students. Asian Social Science, 11(18), 350-363.

Othman, N., \& Othman, S. H. (2017). The perception of public university students of entrepreneurship education in Malaysia. International Business Management, 11(4), 865873.

Othman, N., Othman, N. H., \& Ismail, R. (2012). Impact of globalization on trends in entrepreneurship education in higher education institutions. International Journal Trade, Economics and Finance, 3(4), 267-271.

Othman, N. H., Othman, N., \& Juhdi, N. (2019). Determining the validity and reliability of entrepreneurial emotion. Academy of Entrepreneurship Journal, 25(3), 1-5.

Pless, N. M., Maak, T., \& Stahl, G. (2011). Developing responsible global leaders through international service-learning Programs: The Ulysses experience. Academy of Management Learning and Education, 10(2), 237-260. 
Podsakoff, P. M., MacKenzie, S. B., Lee, J. Y., \& Podsakoff, N. P. (2003). Common Method Biases in Behavioral Research: A Critical Review of the Literature and Recommended Remedies. Journal of Applied Psychology, 88(5), 879-903.

Ramayah,T., Cheah, J., Chuah, F., Ting, H., \& Memon, M.A. (2018). Partial Least Squares Structural Equation Modeling (PLS-SEM) using SmartPLS 3.0. Kuala Lumpur: Pearson Malaysia.

Reynolds, P. D. (2016). Start-up actions and outcomes: What entrepreneurs do to reach profitability? Foundations and Trends in Entrepreneurship, 12(6), 443-559.

Rungtusanatham, M., Miller, J. W., \& Boyer, K. K. (2014). Theorizing, testing and concluding for mediation in SCM research: Tutorial and procedural recommendations. Journal of Operations Management, 32(3), 99-113.

Rusok, N. H. M., Kumar, N., \& Ahmed, A. R. (2017). The effect of entrepreneurship education on entrepreneurial competencies. International Journal of Applied Business and Economic Research, 15(15), 433-455.

Sanchez, V. B., \& Sahuquillo, C. A. (2018). Entrepreneurial intention among engineering students: The role of entrepreneurship education. European Research on Management and Business Economics, 24, 53-61.

Ilonen, S., Heinonen, J., \& Stenholm, P. (2018). Identifying and understanding entrepreneurial decision-making logics in entrepreneurship education. International Journal of Entrepreneurial Behavior \& Research, 24(1), 59-80.

Sarfraz, M., Badar, K., Khattak, A., \& Imtiaz, R. (2018). Are entrepreneurship educators cultivating entrepreneurs? Analysis of transformational attributes. International Journal Business and Society, 9(2), 492-504.

Schmitt, A., Rosing, K., Zhang, S., \& Leatherbee, M. (2017). A dynamic model of entrepreneurial uncertainty and business opportunity identification: exploration as a mediator and entrepreneurial self-efficacy as a moderator. Entrepreneurship Theory and Practice, 1(1), $1-25$.

Sekaran, U., \& Bougie, R. (2016). Research Methods for Business: A Skill Building Approach. United Kingdom: John Wiley \& Sons.

Short, J. C., Ketchen, D. J., Shook, C. L., \& Ireland, R. D. (2010). The concept of "opportunity" in entrepreneurship research: Past accomplishments and future challenges. Journal of Management, 36(1),40-65.

Unger, J. M., Rauch, A., Frese, M., \& Rosenbusch, N. (2011). Human capital and entrepreneurial success: A meta-analytical review. Journal of Business Venturing, 26(1), 341 - 358.

Wah, N. C., Zawawi, D., Yusof, R. N. R., \& Sambasivan, M. (2018). The mediating effect of tacit knowledge sharing in predicting innovative behavior from trust. International Journal of Business and Society, 19(3), 937-954.

Welpe, I. M., Sporrle, M., Grichnik, D., Michl, T., \& Audretsch, D. B. (2012). Emotions and opportunities: The interplay of opportunity evaluation, fear, joy, and anger as antecedent of entrepreneurial exploitation. Entrepreneurship Theory \& Practice, 36(1), 69-96.

Werner, M. J., \& DeSimone, L. R. (2011). Human Resource Development (6 ${ }^{\text {th }}$ Ed). Mason, OH: Cengage.

Zampetakis, L.A., Lerakis, M., Kafetsions, K., \& Moustakis, V. (2016). Anticipated emotions towards new venture creation: A latent profile analysis of early stage career starters. International Journal of Management Education, 14(1), 28-38. 
Zampetakis, L.A., Kafetsios, K., \& Moustakis, V. (2017). Using emotional persuasion for changing attitudes towards entrepreneurship: An interpersonal perspective. Journal of Business Venturing Insights, 7(1), 50-54. 